\title{
Legislative Update
}

\author{
Allison Weber Shuren, NP, JD
}

\section{HOSPITALOUTPATIENTDEPARTMENT PROSPECTIVE PAYMENTSYSTEM}

The Health Care Financing Administration plans to publish the Hospital Outpatient Department Prospective Payment System (HOPD PPS) final rule in early April according to a court document filed recently by the Department of Health and Human Services in connection with a lawsuit filed against DHHS by United American Insurance Co over the delay in implementation of the final rule. It is possible that the document may be on display at the Federal Register office in late March. The HOPD PPS was supposed to be implemented in January 1999, however due to Y2K computer problems at HCFA it was delayed. HCFA now reports it expects implementation in July of this year. In the document DHHS stated that the 700-page regulation was not ready for the slated February 29th publication in large part because of the changes made to the PPS by Congress in the Balanced Budget Refinement Act of 1999 (BBRA) passed late in the last session. Even with the planned July 1 implementation target new concern regarding the readiness of the fiscal intermediaries to transition to the new system has been raised.

\section{STATUS OF ASC PROPOSED RULE}

The Balanced Budget Refinement Act of 1999 directs HCFA to incorporate data from its 1999 Medicare Ambulatory Surgery Center (ASC) survey into the forthcoming ASC payment rule. Alternatively, however, if HCFA is unable to do so, the agency must phase-in the APC system's new ASC rates over a period of at least three years. Until recently, HCFA has maintained the revision of the HOPD PPS and ASC rules on similar timetables. Because the

From Arent Fox Kintner Plotkin \& Kahn, PLLC, Washington, DC. Ms. Shuren is an attorney at Arent Fox and Counsel for Association of Pain Management Anesthesiologists. Address correspondence: Allison Weber Shuren, JD, 1050 Connecticut Avenue NW, Washington, DC 20036 phase-in requirement will slow HCFA's ASC related efforts and cause completion of the ASC rule to lag behind the HOPD PPS final rule, it appears that publication of the two regulations will no longer be linked. Recent reports suggest that final ASC rule will be published in November 2000 with a Spring 2001 implementation. While not confirmed, speculation exists that the extended delay is related to the complexity of the phase-in requirement.

\section{MANAGEDCARECONFEREES BEGINMONUMENTALTASKOFMERGING MANAGED CARE BILLS}

The House-Senate conference committee assigned to merge the House (H.R. 2990) and Senate (S. 1344) managed care reform bills began this monumental task in early March. Given the immense differences between the two bills, much speculation exists as to the possible success of molding a piece a legislation that will be supported by Republicans, Democrats, and the Administration.

The initial strategy of the committee is to tackle several of the less controversial issues. As of March 9th, the committee reached tentative agreement on three provisions included in both the House and Senate bills, including coverage for emergency care, direct access to pediatricians, and provider nondiscrimination. Nevertheless, the most highly contentious issues have yet to reach the table and the deck clearly is stacked against the passage of significant patient protections. The most divisive issues include the appropriate scope of the legislation, the extent of patients right to sue health plans in federal court, liability of managed care plans for adverse patient outcomes, availability of external review of benefit decisions, whether providers or health plans should have the authority to determine medical necessity, and the cost of the legislation. The Congressional Budget Office (CBO) estimated the Senate bill would lead to an average of 1.3 percent increase in premiums, while the House-passed version would result in an increase of 4.1 percent. Furthermore, both the Senate and House Republican conferees solidly oppose the House bill's expansive scope. At the heart of the issue is whether the patient protections should be extended to the some 55 
million Americans in employer self-funded ERISA plans as in the Senate bill, or to all 160 million plus Americans with private health insurance as mandated in the House Patient's Bill of Rights.

Given the significant election year pressures to pass managed care reform, the Republican leadership may be forced to accept significant protections. In addition, Republicans and the conferees are well aware that a limited bill might be faced with the threat of a Clinton veto, as the Administration has made strong statements in the past indicating that the President will only sign a bill containing significant protections. There are signs, nevertheless, that the President may be willing to compromise on some issues and work with the Republicans. For example, White House officials announced that the President would not necessarily oppose a bill that only permits patients to sue their plans in federal court and not in state courts.

\section{Healthcare Integrity and Protection Data Bank Launched}

The new Healthcare Integrity and Protection Data Bank required by the Health Insurance Portability and Accountability Act of 1996 was launched November 22. Different than the National Practitioner Data Bank, which was developed to protect patients by organizing malpractice payment information and adverse licensure and clinical privilege actions, the purpose of the new data bank is to aid in the government's fight against fraud. Under the final rule, state and federal law enforcement, licensing and certifying boards, and health plans are expected to report exclusions of providers from the Federal health care programs, criminal convictions, civil judgments, as well as license actions. Reports regarding provider "overpayments," however, need not be reported.

No entity is required to query the data bank as in the case of the National Practitioner Data bank, but health plans and state and federal agencies may choose to inquire about providers voluntarily. In addition, providers may make self-query of the data bank.

\section{Future of Quality Health-Care Coalition Act of 1999 Uncertain}

Despite strong support from the physician community, including the American Medical Association, the future of Quality Health-Care Coalition Act of 1999 (H.R. 1304) introduced by Tom Campbell (R-CA) is uncertain. Under H.R. 1304 independent/self-employed physicians would be granted exception from the Federal antitrust laws in order to organize for the purposes of bargaining collectively with health plans. Health care professionals would be granted the same rights as other bargaining units under the National Labor Relations Act.

Although the bill was slated to go to Judiciary Committee mark-up during the second week of March, it was postponed due to an extended mark-up of the Fairness in Asbestos Compensation Act. In the interim, challengers of H.R 1304 have gained significant momentum in their efforts to hinder the future of the legislation. Health plans and other business groups are among the most ardent opponents, arguing that the bill will drive up premiums without any commensurate quality improvement. The Federal Trade Commission testified before the Judiciary Committee that the Campbell bill would grant broad antitrust immunity for price fixing, boycotts, and other anticompetitive conduct. This same position has been taken by many nonphysician providers groups concerned that permitting physicians to collectively bargain with health plans could lead to boycotts by the health plans of other providers. The question remains whether House Republicans will be willing to act against the health insurance industry who has stated that H.R. 1304 poses greater threat to their business than the Patient's Bill of Rights.

Nevertheless, the mark-up comes in the wake of two recent changes in the once strongly held view that physicians should not be members of unions. First, the AMA's establishment of a collective bargaining organization for employed medical staff, and second, the recent National Labor Relations Board finding that "house staff" are employees for the purposes of the National Relations Act and therefore, permitted to organize. Currently, there is no Senate companion bill.

\section{MEDICAL ERRORS}

On November 29, 1999, the Institute of Medicine’s Committee on Quality of Health Care in America released To Err is Human: Building a Safer Health System. (The report may be accessed on IOM's home page at http: IIwww.iom.edu). According to the report, between 40,000 and 98,000 lives are lost each year due to medical errors. IOM estimates that of these deaths some 7,000 are related to prescribing errors. In addition, the estimated cost to our health care system for all the errors is \$29 million. 
Release of the startling statistics propelled the medical errors issue to the forefront of the 2000 Congressional agenda. Immediately following release of the report, President Clinton ordered the Federal Quality Interagency Coordination Task Force, which organizes quality control of the federal health programs, to study IOM's findings and make recommendations to decrease the error rate by $50 \%$ in five years. In the past few weeks, both the House and Senate held hearings on the issue of medical errors and Senators Spector, Harkin, and Inouye introduced a bill (S. 2038) which would make grants available to states to establish medical error reporting systems, establish fifteen (15) demonstration projects to assess various types of reporting systems, such as voluntary reporting with disclosure to the Secretary of the HHS and to patients and their families; and authorize grants to health professional associations and other organizations for training and continuing education on reducing medical errors. Kennedy also is working on a legislative proposal with a bipartisan group of Senators on the HELP committee and a bill is expected soon. Representative Bill Thomas, Chairman of the Ways and Means Subcommittee on Health only days ago, reported that the he is exploring the option of tying medical errors reduction legislation to managed care reform legislation.

While there is consensus that the level of medical errors is unacceptable, there is much contention about whether a reporting system should be voluntary or mandatory and how to protect health care professionals when they admit to mistakes or report those by others.

\section{OIG Special Fraud Alert}

On February 23, the HHS-OIG issued a special Fraud Alert, warning physicians that rental amounts for office space must reflect fair market value for the space actually used. In particular, the OIG cautioned that physician landlords who rent space to medical suppliers and/or providers should be aware of the significant Anti-Kickback statute risk if the rental payments are greater than fair market value. The OIG listed the factors it believes are important in evaluating the legality of such arrangements. These factors are (1) the appropriateness of the existence of a rental relationship, (2) the rental amounts, and (3) time and space considerations. The OIG strongly recommended that suppliers and landlord physicians comply with the office space rental safe-harbor to the Anti-Kickback statute.

\section{MEDICAREREFORM AND PRESCRIPTIONDRUG BENEFIT}

In a February meeting between Clinton and congressional leaders on the legislative agenda for 2000, Senator Nickles said Clinton indicated that while Medicare reform was not possible this year, he urged lawmakers to approve a prescription drug benefit. Some members of Congress, such as Senator Wyden, agree with the President that approval of a drug bill should not be contingent upon legislation providing for larger Medicare reform. Others, such as Senators Frist, Breaux, and Hagel believe that it does not make sense to put more money into Medicare without basic reforms. House Ways and Means Subcommittee Chairman Thomas also has rejected action on a stand alone drug bill, on similar grounds.

While broad Medicare reform appears unlikely this session, a full Senate vote on to provide a prescription drug benefit to the Medicare program could take place this spring. The Administration proposed a plan that would permit voluntary coverage to all Medicare beneficiaries where as Republicans in Congress are targeting a much narrower benefit aimed mainly at low-income beneficiaries. On March 9th the Congressional Budget Office reported that the President's proposal would cost Medicare some \$130 billion over a seven year period and the Medicaid program $\$ 19$ billion to subsidize low-income participants drug benefit premiums and co-payments.

Multiple other models for creating a prescription drug benefit have also been offered. Senator Ron Wyden, along with Senator Olympia Snow, has introduced a bill (S. 1480) that would provide drug coverage through Medigap, health maintenance organizations, or other group plans. The drug plan offered by President Clinton last year and again in the Presidents FY 2001 budget would be administered by pharmacy benefit managers under contract with the Health Care Financing Administration. Finally, the drug plan in S. 1895, a Medicare reform bill introduced by Senator Breaux and Senator Frist would provide coverage through private health plans as well as HCFA.

\section{Pain Relief Promotion Act}

The Pain Relief Promotion Act, S.1272, is still pending in the U.S. Senate. This is the companion legislation to H.R. 
2260, passed by the House of Representatives on October 27,1999 . This bill would invalidate Oregon's assisted suicide law by banning the use of federally regulated drugs for assisted suicides and preventing the U.S. Attorney General from recognizing any state law that permits assisted suicide or euthanasia.

The legislation also amends the Controlled Substances Act to provide that alleviating pain or discomfort in the usual course of professional practice is a legitimate medical purpose for the dispensing of a controlled substance that is consistent with public health and safety, even if the use of such a substance may increase the risk of death. Moreover, the bill mandates and pays for training programs in pain management at the local, state and federal level.

The Senate version of the bill has been delayed because it was assigned, apparently by mistake, to two different committees: Committee on Health, Education, Labor, and Pensions (HELP) and the Committee on the Judiciary. Moreover, on January 24, 2000, Senator Ron Wyden (D-OR) asked that a hold be placed on the legislation. A hold is an informal practice by which a Senator informs his floor leader that he does not wish a particular bill to reach the floor for consideration. The Majority Leader need not follow the Senator's wishes, but is on notice that the opposing Senator may filibuster any motion to proceed to consider the measure.

\section{Florida Office Surgery Rules}

The Florida State Medical Board recently enacted new protections that require doctors operating in the office to meet the same standards required in hospitals and surgery centers. By voting 9 - 6 to require an anesthesiologist to supervise office operations in which drugs are given to make a patient unconscious, the state Board of Medicine prompted the end of a legal challenge that had prevented rules it had passed last year from becoming law. In exchange for the adoption of the anesthesiologist requirement, the Florida Society of Anesthesiologists and three hospital associations agreed to end their lawsuit.

Included among the new rules, most of which went into effect on February 17, 2000, are requirements that office surgeons have to register with the state, keep detailed logs and quickly report patient deaths and injuries. Other highlights of the new rules include: a requirement that a "crash cart" of equipment is kept on hand in case of emergency; each office must have at least two people on staff to monitor the patient after surgery, including one certified in advanced cardiac life support, and must keep a ratio of one monitor for two patients; and office surgeons must obtain informed consent from patients after telling them of the potential risks of a procedure, the sedatives to be used and their choices among anesthesia providers. 